Article

\title{
Reusing Desulfurization Slag in Cement Clinker Production and the Influence on the Formation of Clinker Phases
}

\author{
Ying-Liang Chen ${ }^{1, *} \mathbb{D}$, Juu-En Chang ${ }^{1}$ and Ming-Sheng Ko ${ }^{2}$ \\ 1 Department of Environmental Engineering/Sustainable Environment Research Laboratories, \\ National Cheng Kung University, No. 1, University Rd., Tainan City 70101, Taiwan; juuen@mail.ncku.edu.tw \\ 2 Department of Materials and Mineral Resources Engineering, National Taipei University of Technology, \\ Taipei, No. 1, Sec. 3, Chunghsiao E. Rd., Taipei 10608, Taiwan; msko@ntut.edu.tw \\ * Correspondence: roy.yl.chen@gmail.com; Tel.: +886-6-2757575 (ext. 65824)
}

Received: 16 August 2017; Accepted: 5 September 2017; Published: 6 September 2017

\begin{abstract}
The purpose of this study was to investigate the reuse of desulfurization slag in cement clinker production and its influence on the formation of clinker phases. The desulfurization slag that mainly contained $\mathrm{Ca}$ and $\mathrm{Si}$ was identified as non-toxic, and thus it should be suitable to be reused in clinker production. The addition of desulfurization slag increased the melt phase during clinkerization, but the excess melt phase inhibited the formation of clinker phases. This could be attributed to the sulfur and fluoride derived from the De-S slag. At low desulfurization slag addition (5.4 wt \%), the resulting clinker had a mineralogical composition similar to that of the reference clinker. The desulfurization slag added can lower the clinkerization temperature and increase the amount of $\mathrm{Ca}_{3} \mathrm{SiO}_{5}$ at $1300{ }^{\circ} \mathrm{C}$, which may be beneficial to energy conservation in clinker burning. Moreover, reusing desulfurization slag additionally has the potential to reduce the energy needed for clinker grinding.
\end{abstract}

Keywords: desulfurization slag; cement; reuse and recycling; energy saving; waste management; X-ray diffraction

\section{Introduction}

The total world output of cement has grown drastically since the end of the Second World War and currently exceeds 4600 million tons per year [1,2], and the cement industry is one of the largest industrial sources of $\mathrm{CO}_{2}$ emission [3]. Conventional raw materials in cement clinker production include calcareous, siliceous, and argillaceous components, with limestone, sandstone, and clay generally employed. In addition, some materials, such as iron ore and bauxite, are often used to improve the reactivity of a raw mix and reduce the burning temperature. Cement raw mixes can be converted into clinkers by means of a high-temperature sintering process, and there are four major phases typically existing in cement clinkers, namely: alite $\left(\mathrm{Ca}_{3} \mathrm{SiO}_{5}\right)$, belite $\left(\mathrm{Ca}_{2} \mathrm{SiO}_{4}\right)$, aluminate $\left(\mathrm{Ca}_{3} \mathrm{Al}_{2} \mathrm{O}_{6},\right)$, and ferrite $\left(\mathrm{Ca}_{4} \mathrm{Al}_{2} \mathrm{Fe}_{2} \mathrm{O}_{10}\right)$ [4].

In recent years, the supply of suitable natural materials for cement manufacturing has become tighter, and mining the resources often raises environmental issues. Therefore, the cement industry never stops searching for alternative raw materials. Some industrial wastes that are rich in calcium, silicon, or aluminum compounds could have potential for use as cement raw materials. Furthermore, reusing these wastes should be encouraged to save valuable resources and reduce disposal costs. Many researchers have studied the feasibility of wastes for cement production, such as waste marble dust [5], water purification sludge [6], sewage sludge [7], red mud from alumina plants [8], municipal solid waste incinerator ashes [9], and so forth $[10,11]$. In the iron and steel-making industry, the refining 
processes generate various kinds of slags, most of which contain a large amount of lime and/or silica. Blast furnace slag, basic oxygen furnace slag, and electric arc furnace slag have been investigated for cement production and successfully reused as alternative raw materials [12-14]. With regard to desulfurization slag (abbreviated to De-S slag), some studies have been done on reusing De-S slag in controlled low-strength concrete [15] or heavy metal adsorption [16], but little literature is available on cement production.

De-S slag is a byproduct from the desulfurization process in steelmaking. To meet the sulfur limitation in the specifications for steel, it is necessary to lower the sulfur content of liquid iron during secondary steelmaking. A desulfurizer, which normally comprises lime $(\mathrm{CaO})$ and fluorspar $\left(\mathrm{CaF}_{2}\right)$, is added and forms a layer of slag floating on the liquid iron. Sulfur is transferred from the liquid iron to the slag by slag-liquid metal reactions [17]. The basic chemical reaction in desulfurization is given in Equation (1).

$$
\mathrm{Ca}_{(\text {slag })}^{2+}+\mathrm{S}_{(\text {iron })}^{2-} \rightarrow \mathrm{CaS}_{(\text {slag })}
$$

This slag, namely De-S slag, is composed of the desulfurization products, unreacted lime, entrapped iron, and other impurities, e.g., non-ferrous metals and silica. Based on the primary compositions, De-S slag may be considered as an alternative raw material for cement production. However, the impurities in De-S slag may affect the quantity or properties of the melt phase, which forms in the clinkerization process. The formation of clinker phases and the properties of the resulting cement may also be changed due to the impurities. Some previous studies indicated that a low level of foreign ions, including cations and anions, could significantly affect the reactivity of a raw mix $[18,19]$. The viscosity and surface tension of the melt phase could also be affected by the dissolving foreign ions [4]. Moreover, the stabilization of a clinker phase may occur when foreign ions are incorporated into the crystal structure. Kolovos et al. [20] studied the clinkers doped with phosphorous and sulfur compounds, and reported that the melt phase began to form at relatively low temperatures. The viscosity of the melt phase was also reduced when sulfur was present in the clinkerization process. On the other hand, the stabilization of belite by sulfur may have taken place and consequently prevented belite from combining with calcium oxide to form alite. In addition to sulfur, Kacimi et al. [21] reported that a small amount of fluoride in cement raw mixes can significantly affect the clinkerization reactions and the properties of the resulting clinkers. The clinkerization temperature was reduced from $1470{ }^{\circ} \mathrm{C}$ to $1300{ }^{\circ} \mathrm{C}$ by the addition of $1 \mathrm{wt} \%$ of fluorides.

In Taiwan, about 400,000 tons of De-S slag are generated annually, and most of them are not reused or recycled appropriately. Although the amount of heavy metals in De-S slag is normally much lower than that in other kinds of slags, some trace constituents, such as fluoride, may be possible to impact the ecology [22]. As mentioned above, De-S slag has the potential to be an alternative raw material in cement production, and should be considered for reuse in order to achieve better waste management. However, little information is known about the influence of De-S slag on the clinkerization process of cement manufacturing. The purpose of this study was thus to ascertain the feasibility of reusing De-S slag as a cement raw material, and to address the effects on the formation of clinker phases and the characteristics of clinkers.

\section{Materials and Methods}

\subsection{Experimental Materials}

The De-S slag used in this study was collected from a steelmaking plant in Kaohsiung, Taiwan. The tests for moisture, ash content, and loss on ignition were performed immediately after sampling. The dried De-S slag was crushed by a jaw crusher, and a magnetic drum separator was used to separate the iron-rich particles. The magnetic iron-rich particles, which accounted for about $40 \mathrm{wt} \%$ in De-S slag, were removed. The non-magnetic portion of De-S slag was further ground into powder with a particle size below $75 \mu \mathrm{m}$ using a centrifugal ball mill and then carefully stored for the subsequent experiments. 
The chemical composition of De-S slag was determined with an inductively coupled plasma-optical emission spectrometer (ICP-OES, PerkinElmer Optima 2000 DV) following the microwave-assisted acid digestion procedure. The samples were digested with nitric, hydrochloric, and hydrofluoric acids at $175{ }^{\circ} \mathrm{C}$ for $24 \mathrm{~min}$ in a high-performance microwave digestion system (Milestone, START D). The sulfur content of De-S slag was assessed using an elemental analyzer (Elementar Analysensysteme, vario EL). The sulfur in a sample can be oxidized to $\mathrm{SO}_{3}$, and then the concentration of $\mathrm{SO}_{3}$ is detected for quantification. The measurement of fluoride was conducted by following the USEPA Method 340.2 [23]. The leachability of De-S slag was examined according to the toxicity characteristic leaching procedure (TCLP), as described in the USEPA SW-846 Method 1311 [24]. The concentrations of metals in the TCLP extract were analyzed with the ICP-OES.

\subsection{Preparation of Cement Raw Mixes and Clinkers}

The composition of a cement raw mix was calculated on the basis of the chemical moduli, i.e., lime saturation factor (LSF), silica ratio (SR), and alumina ratio (AR), distributed as follows:

$$
\begin{gathered}
\mathrm{LSF}=\frac{\mathrm{CaO}}{2.8 \mathrm{SiO}_{2}+1.2 \mathrm{Al}_{2} \mathrm{O}_{3}+0.65 \mathrm{Fe}_{2} \mathrm{O}_{3}}, \\
\mathrm{SR}=\frac{\mathrm{SiO}_{2}}{\mathrm{Al}_{2} \mathrm{O}_{3}+\mathrm{Fe}_{2} \mathrm{O}_{3}},
\end{gathered}
$$

and

$$
\mathrm{AR}=\frac{\mathrm{Al}_{2} \mathrm{O}_{3}}{\mathrm{Fe}_{2} \mathrm{O}_{3}} .
$$

The values of LSF, SR, and AR were set at 1.00, 2.35, and 1.20, respectively. Six cement raw mixes (C0-C5) were prepared with $0,5.4,10.8,16.2,21.6$, and $27.0 \mathrm{wt} \%$ of De-S slag. Analytical-grade oxides, including $\mathrm{CaO}, \mathrm{SiO}_{2}, \mathrm{Al}_{2} \mathrm{O}_{3}$, and $\mathrm{Fe}_{2} \mathrm{O}_{3}$, were used to adjust the composition to reach the desired values of the chemical moduli. The raw materials containing De-S slag and the oxide powders were homogenized with a centrifugal ball mill to prepare the cement raw mixes. The cement raw mixes were then pelletized into cylindrical pellets of $35 \mathrm{~mm}$ in diameter and approximately $8 \mathrm{~mm}$ in height under a pressure of $9.8 \mathrm{MPa}$. To produce clinkers, the green pellets were sintered in an electric furnace at the temperatures of $1200,1250,1300,1350$, and $1400^{\circ} \mathrm{C}$ for $3 \mathrm{~h}$. After the sintering process, the clinkers were cooled to room temperature in the furnace and then ground into powder for further analyses.

\subsection{Quantitative X-ray Diffraction Analysis}

To acquire the mineralogical compositions of the clinkers, X-ray powder diffractometry (XRPD) was carried out using an X-ray diffractometer (Bruker D8 Advance) with $\mathrm{Cu} K \alpha$ radiation. A clinker was mixed with high-crystallinity corundum $\left(\alpha-\mathrm{Al}_{2} \mathrm{O}_{3}\right)$, as an internal standard, in the weight ratio of 10:1. This mixture was dispersed in a $0.5 \%(\mathrm{w} / \mathrm{v})$ aqueous solution of polyvinyl alcohol to form a suspension in which the solid-to-liquid ratio was 1:2. The suspension was then immediately spray dried using a device similar to that described by Hillier [25], and the resulting granules were collected for XRPD analysis. XRPD patterns were recorded by a step-scanning mode in the angle interval of $20-70^{\circ}(2 \theta)$. Clinker phases were identified by comparing with the Powder Diffraction File (PDF) cards published by the International Centre for Diffraction Data (ICDD). The quantitative phase analysis was performed by the reference intensity ratio (RIR) method, which is an adaptation of the internal standard method [26-28]. The most general definition of RIR for the phase of interest $\alpha$ and the reference phase $\mathrm{s}$ is given by Equation (5).

$$
\operatorname{RIR}_{\alpha, \mathrm{s}}=\left(\frac{\mathrm{I}_{(\mathrm{hkl}) \alpha}}{\mathrm{I}_{(\mathrm{hkl})^{\prime} \mathrm{s}}}\right)\left(\frac{\mathrm{I}_{(\mathrm{hkl})^{\prime} \mathrm{s}}^{\mathrm{rel}}}{\mathrm{I}_{(\mathrm{hkl}) \alpha}^{\mathrm{rel}}}\right)\left(\frac{\mathrm{X}_{\mathrm{s}}}{\mathrm{X}_{\alpha}}\right),
$$


where X, I, and $\mathrm{I}^{\text {rel }}$ denote the weight fraction, intensity of a diffraction peak, and relative intensity, respectively. $\mathrm{I}_{(\mathrm{hkl})^{\prime} \mathrm{s}}$ and $\mathrm{I}_{(\mathrm{hkl})^{\prime} \alpha}$ can be calculated from the experimental diffraction data, and the three required constants $\left(\mathrm{I}_{(\mathrm{hkl}) \mathrm{s}_{\mathrm{s}}}^{\mathrm{rel}} \mathrm{I}_{(\mathrm{hkl}) \alpha}^{\mathrm{rel}}\right.$, and $\left.\mathrm{RIR}_{\alpha, \mathrm{cor}}\right)$ can be taken from the ICDD-PDF cards. Table 1 shows

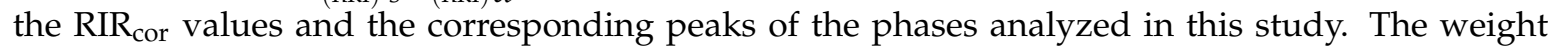
fraction of phase $\alpha$ in the XRPD specimen $\left(X_{\alpha}\right)$ can be obtained from the known $X_{c o r}$, and thus in the original sample $\left(\mathrm{X}_{\alpha}^{\prime}\right)$ can be computed by Equation (6).

$$
X_{\alpha}^{\prime}=\frac{X_{\alpha}}{1-X_{\text {cor }}} .
$$

However, the results of the RIR method in this study should be considered as semi-quantitative, because this analysis is based on the tabulated constants from ICDD-PDF cards.

Table 1. RIR cor values of phases and the corresponding peaks used in the quantitative phase analysis.

\begin{tabular}{cccccc}
\hline \multirow{2}{*}{ Phase } & \multirow{2}{*}{ Chemical Formula } & RIR $_{\text {cor }}$ & \multicolumn{3}{c}{ Peak } \\
\cline { 4 - 6 } & & & d-Spacing (Å) & h k 1 & I rel \\
\hline Tricalcium silicate & $\mathrm{Ca}_{3} \mathrm{SiO}_{5}$ & 1.28 & 1.76 & 220 & 66.5 \\
$\beta$-dicalcium silicate & $\mathrm{Ca}_{2} \mathrm{SiO}_{4}$ & 0.76 & 2.88 & 120 & 27.8 \\
$\gamma$-dicalcium silicate & $\mathrm{Ca}_{2} \mathrm{SiO}_{4}$ & 1.30 & 4.32 & 021 & 33.9 \\
Corundum ${ }^{1}$ & $\mathrm{Al}_{2} \mathrm{O}_{3}$ & 1.00 & 3.48 & 012 & 75.0 \\
\hline \multicolumn{2}{c}{${ }^{1}$ Reference phase. }
\end{tabular}

\subsection{Other Analyses}

The fusibility tests of the raw mixes were performed according to a method modified from ASTM D1857/D1857M-17 [29]. Triangular cones that were $19 \mathrm{~mm}$ in height and $6.4 \mathrm{~mm}$ in width on each side of the base were prepared with the raw mixes, and then gradually heated to $1400{ }^{\circ} \mathrm{C}$ at a rate of $10^{\circ} \mathrm{C} / \mathrm{min}$. Two critical temperature points were observed. Softening temperature (ST) was observed when a cone had fused down to a spherical lump in which the height was equal to the width at the base. Fluid temperature (FT) was defined as the temperature at which the fused mass spread out to a nearly flat layer. Thermal analysis was used to observe the reactions taking place during the sintering process, which used a simultaneous differential scanning calorimetry and thermogravimetric analyzer (DSC-TGA, TA SDT 2960). The temperature was programmed to rise at a heating rate of $10{ }^{\circ} \mathrm{C} / \mathrm{min}$ from room temperature to $1400{ }^{\circ} \mathrm{C}$. The furnace atmosphere was air, and the gas flow rate was $100 \mathrm{~mL} / \mathrm{min}$. The particle size distribution of a clinker powder was measured using a laser diffraction particle size analyzer (Beckman Coulter, LS 230).

Generally, the experimental procedure and the methods/analyses used in this study are illustrated in Figure 1.

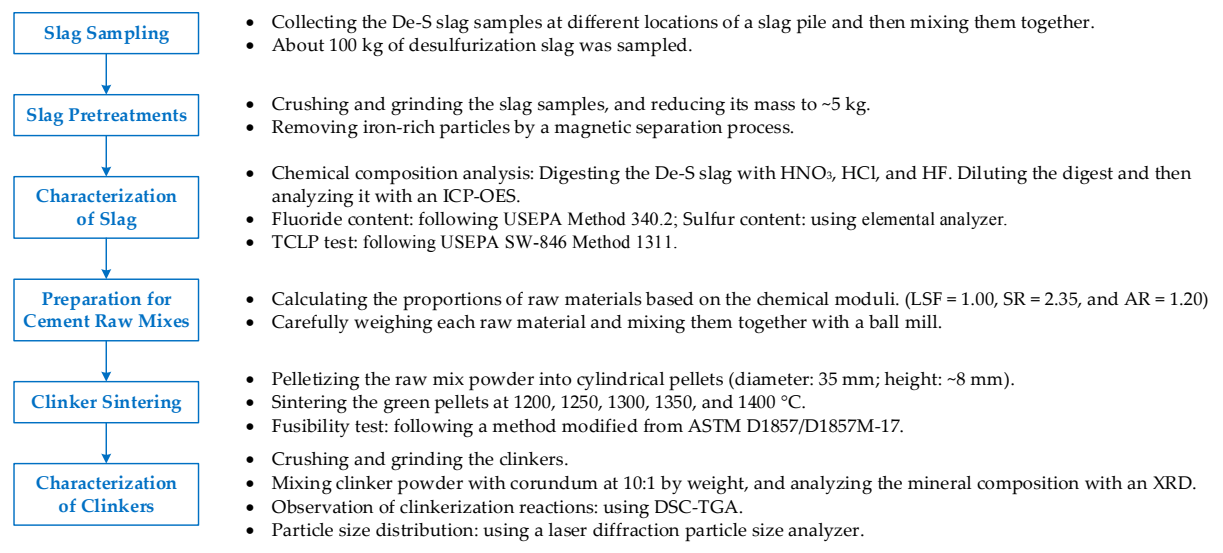

Figure 1. The experimental flow chart of this study. 


\section{Results and Discussion}

\subsection{Characterization of De-S Slag}

The moisture and ash content of the De-S slag were $6.6 \mathrm{wt} \%$ and $81.2 \mathrm{wt} \%$, respectively, and the loss on ignition was $12.2 \mathrm{wt} \%$. The loss on ignition should be partially attributed to the Kish graphite that is precipitated from carbon-saturated liquid iron [30]. It is suggested that the high ash content (86.9 wt \% on dry basis) of the De-S slag is beneficial to a cement raw material. Table 2 shows the results of the chemical analyses and the TCLP test for the De-S slag. The major elements in the De-S slag were $\mathrm{Ca}(48.92 \mathrm{wt} \%)$ and Si (17.83 wt \%), while the other essential elements for a cement raw mix, namely $\mathrm{Al}$ and $\mathrm{Fe}$, were also present at $2.15 \mathrm{wt} \%$, and $2.89 \mathrm{wt} \%$, respectively. Compared with the original De-S slag, which often contains about 10-20 wt \% iron and iron compounds, the results suggest that the magnetic-separation process is effective in lowering the Fe content, and the magnetic particles removed from the De-S slag could be considered for iron recovery. Some alkali and alkaline-earth metals, including $\mathrm{Na}, \mathrm{K}$, and $\mathrm{Mg}$, were also detected at 0.37-2.63 wt \%. In addition, small amounts of sulfur, fluoride, and heavy metals (such as $\mathrm{Zn}, \mathrm{Mn}$, and $\mathrm{Cu}$ ) were present in the De-S slag, and these trace constituents may influence the clinkerization reactions. In terms of the TCLP test, the results showed that only $\mathrm{Ca}^{2+}$ and a few alkali ions were leached out, whereas the concentrations of heavy metals were all below the detection limits. The $\mathrm{pH}$ value of the TCLP extract increased from 2.88 to 12.40 after the leaching test. These findings imply that the heavy metals are fixed in the De-S slag, which is presumably due to the high alkalinity of De-S slag. In Taiwan, industrial waste must be examined using the TCLP test to identify its toxicity before external reuse or recycling. From the above results, the De-S slag should be considered non-toxic and suitable for recycling uses.

Table 2. Results of chemical analysis and toxicity characteristic leaching procedure (TCLP) test for De-S slag.

\begin{tabular}{ccc}
\hline Element & Weight Percentage (wt $\%)$ & Concentration in TCLP Extract $(\mathbf{m g} / \mathbf{L})$ \\
\hline $\mathrm{Ca}$ & $48.92 \pm 2.85$ & $2980 \pm 52$ \\
$\mathrm{Si}$ & $17.83 \pm 1.67$ & $0.58 \pm 0.13$ \\
$\mathrm{Al}$ & $2.15 \pm 0.29$ & $0.07 \pm 0.01$ \\
$\mathrm{Fe}$ & $2.89 \pm 0.24$ & $\mathrm{ND}^{1}$ \\
$\mathrm{Mg}$ & $0.37 \pm 0.11$ & $\mathrm{ND}^{1}$ \\
$\mathrm{Na}$ & $2.63 \pm 0.02$ & $1.57 \pm 0.01$ \\
$\mathrm{~K}$ & $0.61 \pm 0.01$ & $1.01 \pm 0.02$ \\
$\mathrm{Mn}$ & $0.12 \pm 0.02$ & $\mathrm{ND}^{1}$ \\
$\mathrm{Cu}$ & $0.03 \pm 0.01$ & $\mathrm{ND}^{1}$ \\
$\mathrm{Zn}$ & $0.22 \pm 0.01$ & $\mathrm{ND}^{1}$ \\
$\mathrm{Cr}$ & $\mathrm{ND}$ & $\mathrm{ND}^{1}$ \\
$\mathrm{Ni}$ & $\mathrm{ND}$ & $\mathrm{ND}^{1}$ \\
$\mathrm{~Pb}$ & $\mathrm{ND}^{1}$ & $\mathrm{ND}^{1}$ \\
$\mathrm{Cd}$ & $\mathrm{ND}^{1}$ & $\mathrm{ND}^{1}$ \\
$\mathrm{~S}$ & $1.62 \pm 0.19$ & $\mathrm{NA}^{2}$ \\
$\mathrm{~F}$ & $0.39 \pm 0.03$ & $\mathrm{NA}^{2}$ \\
\hline
\end{tabular}

${ }^{1}$ ND: not detected. ${ }^{2}$ NA: not available.

\subsection{Influence of De-S slag Addition}

Figure 2 shows the XRPD patterns of the clinkers C0-C5 sintered at $1400{ }^{\circ} \mathrm{C}$. The clinker C0 was produced without the De-S slag, and was regarded as a reference clinker. The predominant crystalline phases in the clinker $\mathrm{C} 0$ were $\mathrm{Ca}_{3} \mathrm{SiO}_{5}, \mathrm{Ca}_{3} \mathrm{Al}_{2} \mathrm{O}_{6}$, and $\mathrm{Ca}_{4} \mathrm{Al}_{2} \mathrm{Fe}_{2} \mathrm{O}_{10}$. The mineralogical composition of the clinker $\mathrm{C} 1$ was similar to that of the clinker $\mathrm{C} 0$, except for $\mathrm{CaO}$. It was observed that $\mathrm{CaO}$ began to appear in the clinker $\mathrm{C} 1$, and its diffraction intensity increased with the amount of the De-S slag added. In the clinkers $\mathrm{C} 2-\mathrm{C} 5$, the diffraction intensity of $\mathrm{Ca}_{3} \mathrm{SiO}_{5}$ significantly decreased, and 
there were no clear diffraction peaks of $\mathrm{Ca}_{4} \mathrm{Al}_{2} \mathrm{Fe}_{2} \mathrm{O}_{10}$ observed. When the amount of the De-S slag reached $27.0 \mathrm{wt} \%$ (clinker $\mathrm{C} 5$ ), the diffraction intensity of $\mathrm{Ca}_{3} \mathrm{SiO}_{5}$ was very weak, whereas jasmundite $\left(\mathrm{Ca}_{11}\left(\mathrm{SiO}_{4}\right)_{4} \mathrm{O}_{2} \mathrm{~S}\right)$ was distinctly observed. Some researchers [31] studied the crystal structure of jasmundite and concluded that the sulfur is present not as a sulfate group, but as sulfide species. The results suggest that the $\mathrm{CaS}$ in the De-S slag should be preserved and incorporated into jasmundite during the clinkerization process.

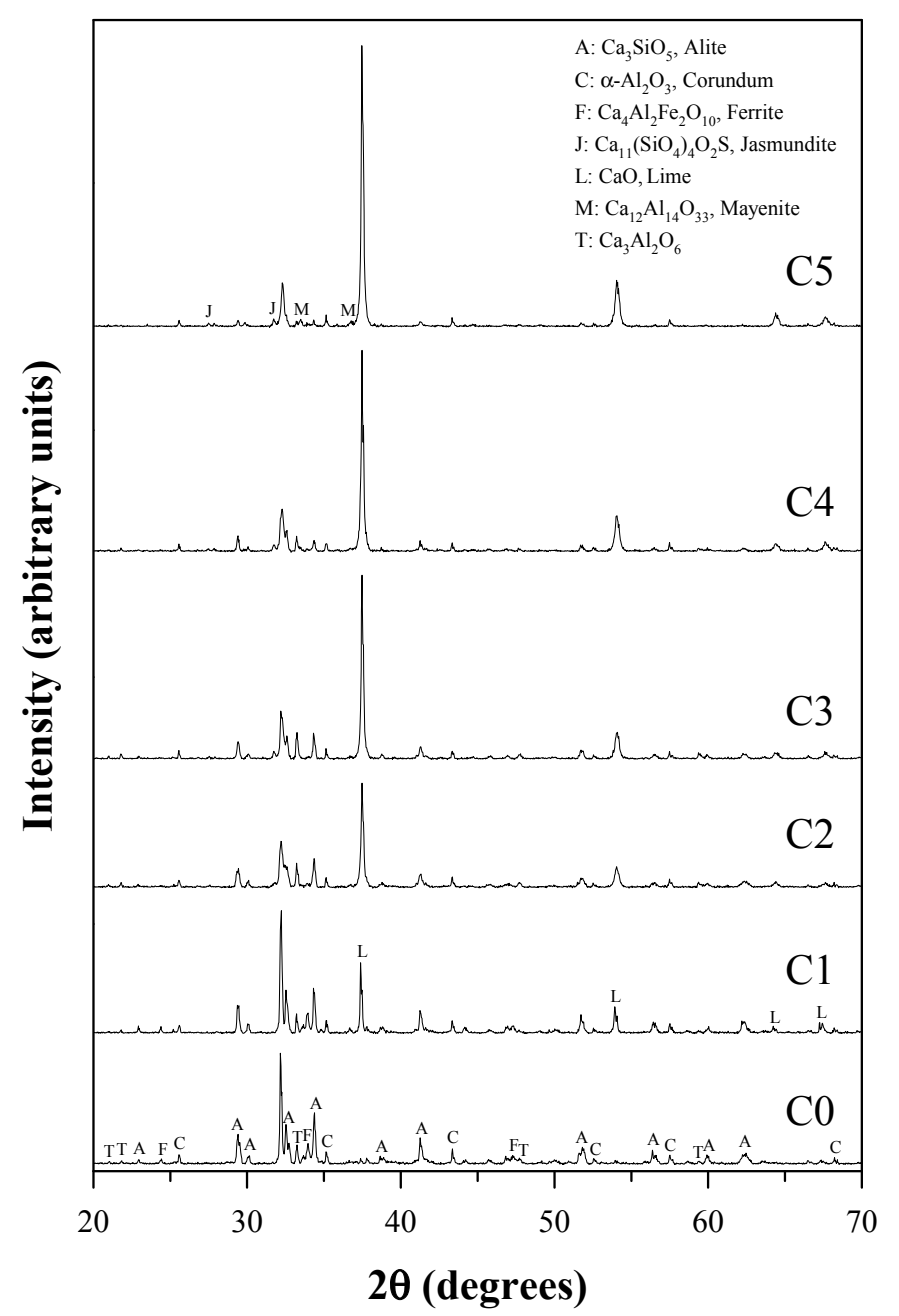

Figure 2. X-ray powder diffractometry (XRPD) patterns of the clinkers $\mathrm{C} 0-\mathrm{C} 5$ sintered at $1400{ }^{\circ} \mathrm{C}$.

By using the RIR method for quantitative phase analysis, the amounts of $\mathrm{Ca}_{3} \mathrm{SiO}_{5}$ in the clinkers $\mathrm{C} 0-\mathrm{C} 5$ sintered at $1400{ }^{\circ} \mathrm{C}$ are presented in Figure 3. The quantity of $\mathrm{Ca}_{3} \mathrm{SiO}_{5}$ was close to $50 \mathrm{wt} \%$ when the amount of De-S slag added was between 0 and $5.4 \mathrm{wt} \%$, and it decreased dramatically when the amount of De-S slag was over $5.4 \mathrm{wt} \%$. The clinker produced with $27.0 \mathrm{wt} \%$ of the De-S slag contained only $\sim 11 \mathrm{wt} \%$ of $\mathrm{Ca}_{3} \mathrm{SiO}_{5}$. The results show that the De-S slag has a significant effect on the formation of $\mathrm{Ca}_{3} \mathrm{SiO}_{5}$. Some previous studies [20,32] found that the $\mathrm{CaO}$ and $\mathrm{Ca}_{2} \mathrm{SiO}_{4}$ that remain in clinkers often increase simultaneously as $\mathrm{Ca}_{3} \mathrm{SiO}_{5}$ decreases, because $\mathrm{Ca}_{2} \mathrm{SiO}_{4}$ is stabilized by some elements, thus inhibiting the combination with $\mathrm{CaO}$ to form $\mathrm{Ca}_{3} \mathrm{SiO}_{5}$. However, there was little $\mathrm{Ca}_{2} \mathrm{SiO}_{4}$ observed in the XRPD patterns of the clinkers in this study. This indicates that the interference in $\mathrm{Ca}_{3} \mathrm{SiO}_{5}$ formation at high levels of De-S slag should not be attributed to the stabilization of $\mathrm{Ca}_{2} \mathrm{SiO}_{4}$, and there should be other reasons for the results. 


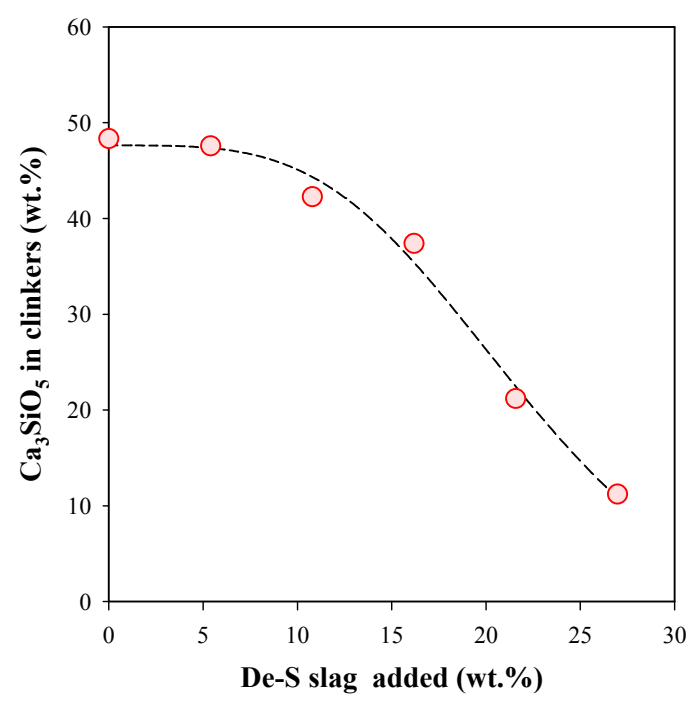

Figure 3. Weight percentages of $\mathrm{Ca}_{3} \mathrm{SiO}_{5}$ in the clinkers produced with different amounts of De-S slag at $1400{ }^{\circ} \mathrm{C}$.

Figure 4 shows the images of the clinkers $\mathrm{C} 0-\mathrm{C} 5$ sintered at $1400{ }^{\circ} \mathrm{C}$. Based on the melting status, the clinkers can be divided into three groups. (1) The clinker $\mathrm{C} 0$ had no obvious melting status. It maintained the shape of the green pellet and had only a little shrinkage. (2) The clinkers $C 1$ and C2 partially melted. (3) The clinkers C3-C5, in which the amount of De-S slag ranged from 16.2 to $27.0 \mathrm{wt} \%$, completely melted, and partial vitrification was observed in the clinker C5. Table 3 lists the results of the fusibility tests for the cement raw mixes. For the raw mixes $\mathrm{C} 0$ and $\mathrm{C} 1$, there were no ST points recorded up to $1400^{\circ} \mathrm{C}$. The raw mix C2 had a ST point of $1390^{\circ} \mathrm{C}$, which was higher than those seen for raw mixes $\mathrm{C} 3-\mathrm{C} 5\left(1365-1370{ }^{\circ} \mathrm{C}\right)$. In terms of FT, the raw mixes $\mathrm{C} 0-\mathrm{C} 2$ had no FT points observed, while the raw mixes C3-C5 had similar FT points between 1390 and $1395^{\circ} \mathrm{C}$. The reduction in ST and FT points supports the claim that more melt phase is formed when more De-S slag is added. Dominguez et al. [33] studied the effects of $\mathrm{CaF}_{2}$ on the sinterization of Portland clinkers, and reported that a trace amount of $\mathrm{CaF}_{2}(<0.4 \mathrm{wt} \%)$ can significantly reduce the formation temperature of the melt phase. Accordingly, the fluoride derived from the De-S slag may also be responsible for the changes in melting status of the clinkers.

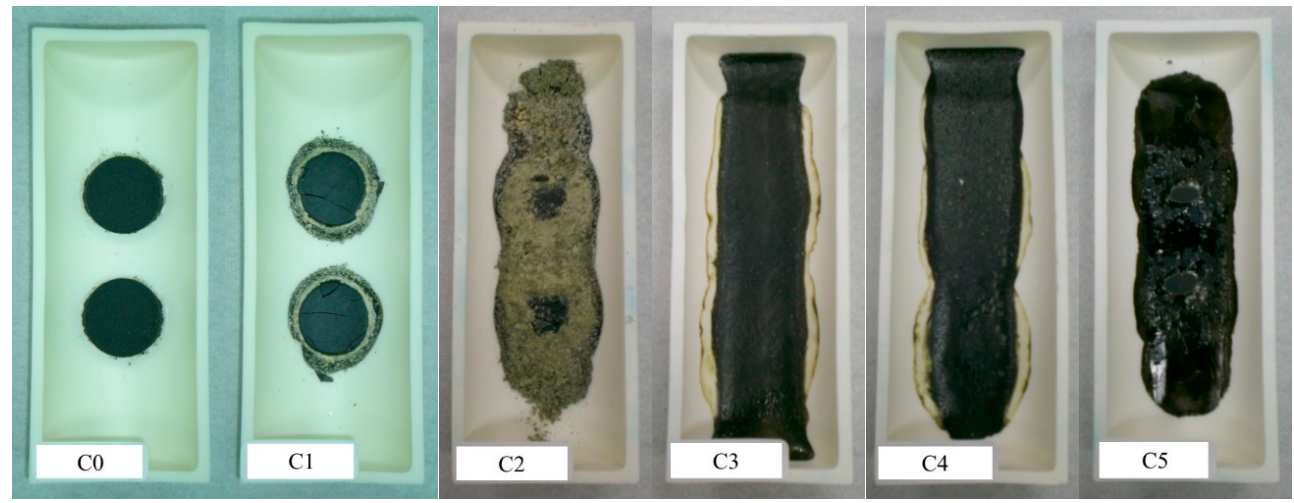

Figure 4. The pictures of the clinkers $\mathrm{C} 0-\mathrm{C} 5$ sintered at $1400^{\circ} \mathrm{C}$. 
Table 3. Results of fusibility tests for cement raw mixes.

\begin{tabular}{ccc}
\hline Raw Mix & ST $\left({ }^{\circ} \mathbf{C}\right)$ & FT $\left({ }^{\circ} \mathbf{C}\right)$ \\
\hline C0 & -1 & -1 \\
C1 & -1 & $-{ }^{1}$ \\
C2 & 1390 & $-{ }^{1}$ \\
C3 & 1365 & 1390 \\
C4 & 1370 & 1395 \\
C5 & 1370 & 1390 \\
\hline \multicolumn{2}{c}{${ }^{1}$ Not observed up to $1400{ }^{\circ} \mathrm{C}}$.
\end{tabular}

The results of the fusibility tests demonstrated that the raw mixes prepared with $16.2-27.0 \mathrm{wt} \%$ of the De-S slag completely melted at $1400{ }^{\circ} \mathrm{C}$. This indicates that the addition of De-S slag can promote the formation of a melt phase, and thus increase the quantity of the melt phase at $1400{ }^{\circ} \mathrm{C}$. By considering the changes in the clinker phases together, it was found that the increase in the quantity of melt phase may be ascribed to the dissolution of interstitial phases or other intermediates, e.g., $\mathrm{Ca}_{4} \mathrm{Al}_{2} \mathrm{Fe}_{2} \mathrm{O}_{10}$ and $\mathrm{Ca}_{2} \mathrm{SiO}_{4}$. When the amount of De-S slag was at 10.8-27.0 wt \%, $\mathrm{Ca}_{4} \mathrm{Al}_{2} \mathrm{Fe}_{2} \mathrm{O}_{10}$ disappeared, and $\mathrm{Ca}_{3} \mathrm{SiO}_{5}$ markedly decreased. $\mathrm{Ca}_{2} \mathrm{SiO}_{4}$ may not have been observed in the clinkers because it also dissolved in the melt phase. Telschow et al. [4] indicated that the nodulization of clinkers requires an adequate proportion of melt phase. In this study, however, the quantity of the melt phase was excessive when adding too much De-S slag in a raw mix, and this may result in the interference in the formation of $\mathrm{Ca}_{3} \mathrm{SiO}_{5}$. Bădănoiu et al. [34] reported that the presence of fluoride can promote the formation of melt phase at lower temperatures and in higher amounts. Accordingly, the excess melt phase observed in this work may be attributed to the fluoride introduced by the De-S slag. In general, the formation of $\mathrm{Ca}_{3} \mathrm{SiO}_{5}$ depends on the quantity and properties of the melt phase. The increase in the quantity of the melt phase can provide more space for the formation and growth of $\mathrm{Ca}_{3} \mathrm{SiO}_{5}$. However, an excess melt phase means many of the materials are dissolved and consumed, thus retarding $\mathrm{Ca}_{3} \mathrm{SiO}_{5}$ formation.

\subsection{Mineralogical Composition of Clinkers at Different Temperatures}

The above results show that the addition of De-S slag can substantially increase the quantity of the melt phase, but interfere with the formation of $\mathrm{Ca}_{3} \mathrm{SiO}_{5}$ when the level of addition reaches $10.8-27.0 \mathrm{wt} \%$. The suggested amount of De-S slag addition is thus below $5.4 \mathrm{wt} \%$, and further examinations for clinkers $\mathrm{C} 0$ and $\mathrm{C} 1$ were subsequently conducted. Figure 5 shows the XRPD patterns of the clinkers $\mathrm{C} 0$ and $\mathrm{C} 1$ sintered at $1200-1400{ }^{\circ} \mathrm{C}$. In Figure $5 \mathrm{a}, \mathrm{CaO}$ and typical clinker phases, including $\mathrm{Ca}_{3} \mathrm{SiO}_{5}, \mathrm{Ca}_{2} \mathrm{SiO}_{4}, \mathrm{Ca}_{3} \mathrm{Al}_{2} \mathrm{O}_{6}$, and $\mathrm{Ca}_{4} \mathrm{Al}_{2} \mathrm{Fe}_{2} \mathrm{O}_{10}$, can be found at different sintering temperatures. $\mathrm{CaO}$ and $\beta-\mathrm{Ca}_{2} \mathrm{SiO}_{4}$ were the predominant phases in the clinker sintered at $1200{ }^{\circ} \mathrm{C}$, and srebrodolskite $\left(\mathrm{Ca}_{2} \mathrm{Fe}_{2} \mathrm{O}_{5}\right)$ was also found. The clinker phases at $1250{ }^{\circ} \mathrm{C}$ were similar to those at $1200{ }^{\circ} \mathrm{C}$, except the diffraction peaks of $\gamma-\mathrm{Ca}_{2} \mathrm{SiO}_{4}$ were more obvious. When the sintering temperature was $1300{ }^{\circ} \mathrm{C}$, there were several phases, including $\mathrm{CaO}, \beta-\mathrm{Ca}_{2} \mathrm{SiO}_{4}, \gamma-\mathrm{Ca}_{2} \mathrm{SiO}_{4}, \mathrm{Ca}_{3} \mathrm{SiO}_{5}, \mathrm{Ca}_{2} \mathrm{Fe}_{2} \mathrm{O}_{5}$, and $\mathrm{Ca}_{3} \mathrm{Al}_{2} \mathrm{O}_{6}$, coexisting in the clinker. This sintering temperature is regarded as a transition stage in the clinkerization process. In the clinker sintered at $1350{ }^{\circ} \mathrm{C}, \mathrm{Ca}_{3} \mathrm{SiO}_{5}$ became a predominant phase, and $\mathrm{Ca}_{3} \mathrm{Al}_{2} \mathrm{O}_{6}$ and $\mathrm{Ca}_{4} \mathrm{Al}_{2} \mathrm{Fe}_{2} \mathrm{O}_{10}$ were also present. In contrast to $\mathrm{Ca}_{3} \mathrm{SiO}_{5}, \beta-\mathrm{Ca}_{2} \mathrm{SiO}_{4}$ and $\gamma-\mathrm{Ca}_{2} \mathrm{SiO}_{4}$ began to disappear at $1350{ }^{\circ} \mathrm{C}$. The clinkers sintered at 1400 and $1350{ }^{\circ} \mathrm{C}$ had similar crystalline phases, except the diffraction intensity of $\mathrm{CaO}$ was much lower at $1400^{\circ} \mathrm{C}$. 


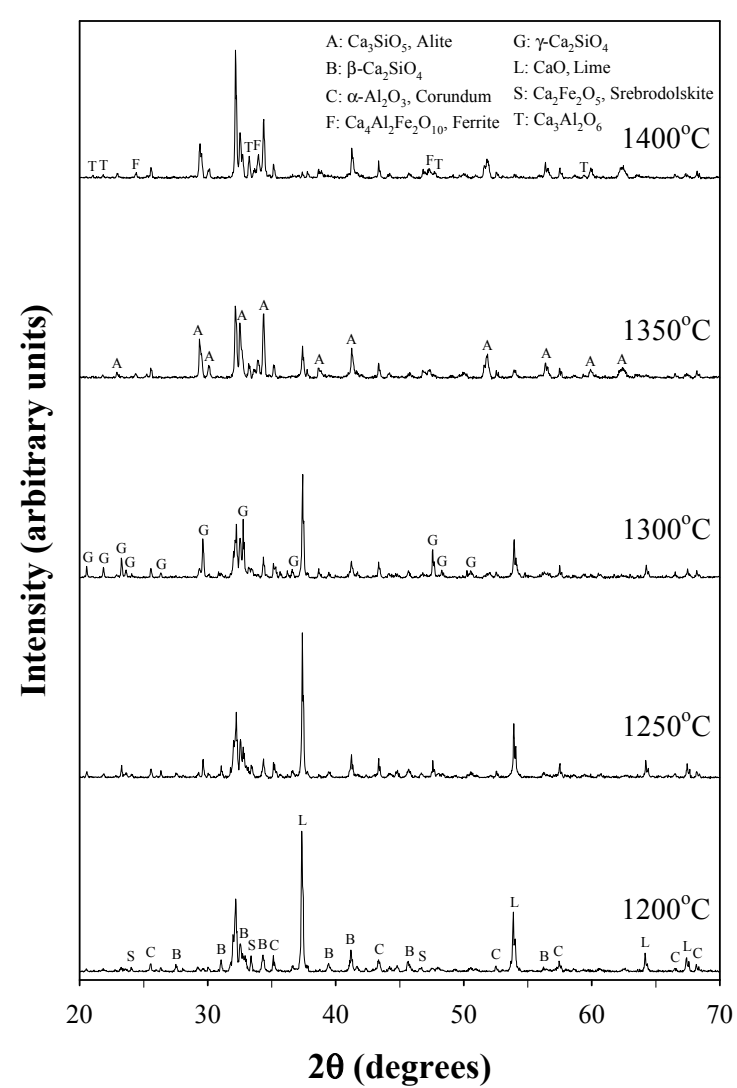

(a)

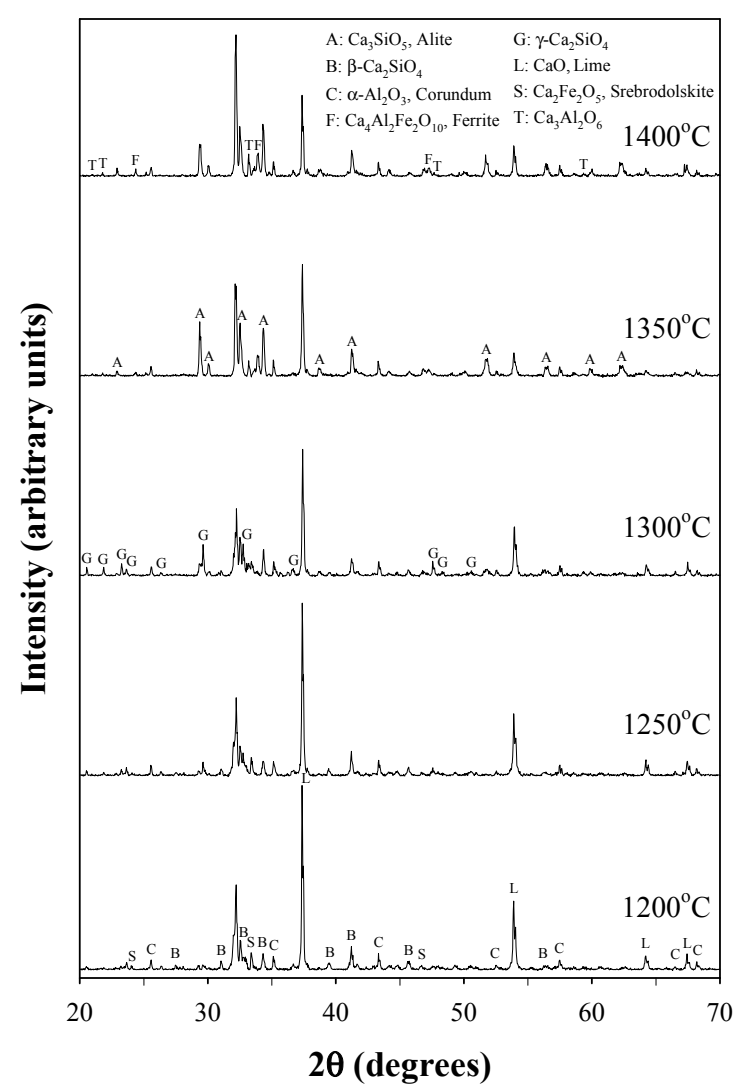

(b)

Figure 5. XRPD patterns of the clinkers sintered at 1200-1400 ${ }^{\circ} \mathrm{C}$ : (a) Clinker C0; (b) Clinker C1.

In Figure $5 b$, the variation of the crystalline phases in the clinker $\mathrm{C} 1$ between 1200 and $1400{ }^{\circ} \mathrm{C}$ broadly resembles that in the clinker $\mathrm{C} 0$. From 1200 to $1300{ }^{\circ} \mathrm{C}$, the diffraction intensity of $\beta-\mathrm{Ca}_{2} \mathrm{SiO}_{4}$ decreased while that of $\gamma-\mathrm{Ca}_{2} \mathrm{SiO}_{4}$ increased. $\mathrm{Ca}_{3} \mathrm{SiO}_{5}$ was clearly observed from $1300{ }^{\circ} \mathrm{C}$, and became the predominant clinker phase at 1350 and $1400{ }^{\circ} \mathrm{C} . \mathrm{Ca}_{3} \mathrm{Al}_{2} \mathrm{O}_{6}$ and $\mathrm{Ca}_{4} \mathrm{Al}_{2} \mathrm{Fe}_{2} \mathrm{O}_{10}$ were present in the clinkers sintered above $1300{ }^{\circ} \mathrm{C}$. It is noted that $\mathrm{CaO}$ is the major difference between the clinkers $\mathrm{C} 0$ and $\mathrm{C} 1$. The clinker $\mathrm{C} 1$ had a stronger diffraction intensity of $\mathrm{CaO}$ than the clinker $\mathrm{C} 0$, particularly at 1350 and $1400{ }^{\circ} \mathrm{C}$. These results show that De-S slag addition of $5.4 \mathrm{wt} \%$ does not significantly affect the formation temperature of a clinker phase, but may cause a change in the quantity at a specific sintering temperature.

Figure 6 shows the variations in the quantity of the phases in the clinkers $\mathrm{C} 0$ and $\mathrm{C} 1$ from 1200 to $1400{ }^{\circ} \mathrm{C}$. Generally, $\mathrm{Ca}_{3} \mathrm{SiO}_{5}$ increased whereas $\beta-\mathrm{Ca}_{2} \mathrm{SiO}_{4}$ decreased with the increase in sintering temperature; moreover, $\gamma-\mathrm{Ca}_{2} \mathrm{SiO}_{4}$ increased at $1200-1300{ }^{\circ} \mathrm{C}$, and then decreased at $1300-1400{ }^{\circ} \mathrm{C}$. Previous research on the $\beta \rightarrow \gamma$ transformation of $\mathrm{Ca}_{2} \mathrm{SiO}_{4}$ [35] attributed the increase of $\gamma-\mathrm{Ca}_{2} \mathrm{SiO}_{4}$ to the enlargement of crystallite size of $\mathrm{Ca}_{2} \mathrm{SiO}_{4}$, which occurs due to the rise in sintering temperature. This may be an explanation for the increase of $\gamma-\mathrm{Ca}_{2} \mathrm{SiO}_{4}$ at $1200-1300{ }^{\circ} \mathrm{C}$. Between 1300 and $1350{ }^{\circ} \mathrm{C}$, there were drastic variations in the quantity of the three clinker phases. The clinkers sintered at 1200 and $1250{ }^{\circ} \mathrm{C}$ only contained a small amount of $\mathrm{Ca}_{3} \mathrm{SiO}_{5}$, but the amount of $\mathrm{Ca}_{3} \mathrm{SiO}_{5}$ greatly increased from below $5 \mathrm{wt} \%$ to over $40 \mathrm{wt} \%$ between 1250 and $1350{ }^{\circ} \mathrm{C}$, especially at $1300-1350{ }^{\circ} \mathrm{C}$. Above $1350{ }^{\circ} \mathrm{C}$, the increase in $\mathrm{Ca}_{3} \mathrm{SiO}_{5}$ tended to be insignificant. The results suggest that the variations of $\beta-\mathrm{Ca}_{2} \mathrm{SiO}_{4}$ and $\gamma-\mathrm{Ca}_{2} \mathrm{SiO}_{4}$ are highly associated with the formation of $\mathrm{Ca}_{3} \mathrm{SiO}_{5}$, and the temperature range between 1300 and $1350{ }^{\circ} \mathrm{C}$ seems to be the crucial stage in the clinkerization process. 


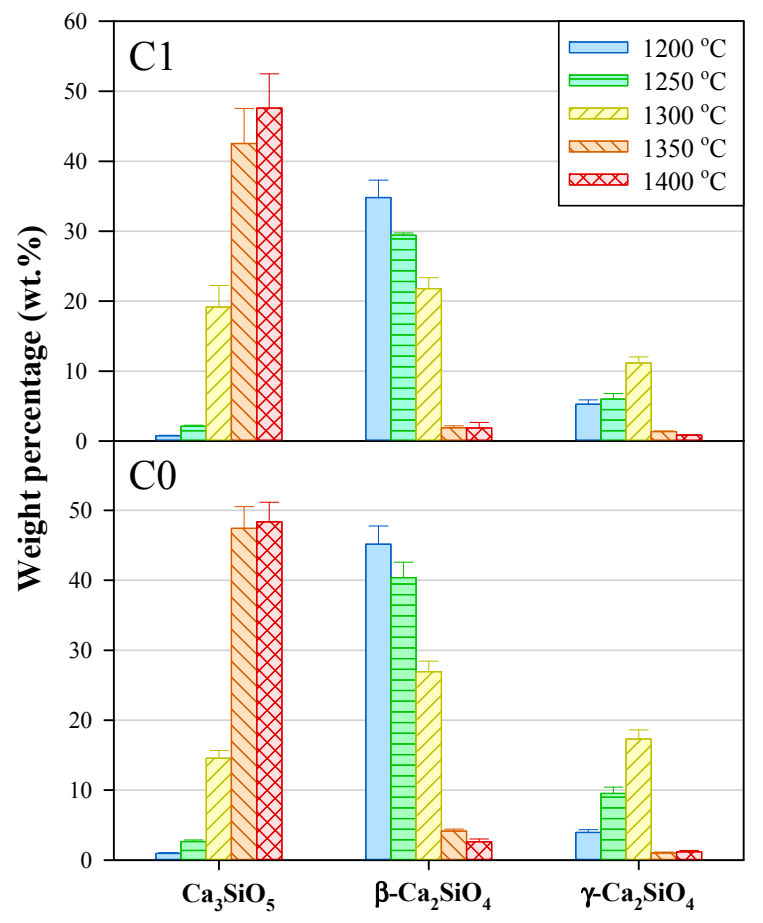

Figure 6. Results of quantitative phase analysis of the clinkers $\mathrm{C} 0$ and $\mathrm{C} 1$ sintered at $1200-1400{ }^{\circ} \mathrm{C}$.

It is noted that both the clinkers $\mathrm{C} 0$ and $\mathrm{C} 1$ contained little $\mathrm{Ca}_{3} \mathrm{SiO}_{5}$ at 1200 and $1250{ }^{\circ} \mathrm{C}$, but the clinker $\mathrm{C} 1$ had more $\mathrm{Ca}_{3} \mathrm{SiO}_{5}$ than the clinker $\mathrm{C} 0$ at $1300{ }^{\circ} \mathrm{C}$. This shows that the De-S addition of $5.4 \mathrm{wt} \%$ can reduce the initial formation temperature of $\mathrm{Ca}_{3} \mathrm{SiO}_{5}$ and increase the quantity of $\mathrm{Ca}_{3} \mathrm{SiO}_{5}$ at a low temperature. Furthermore, the clinker $\mathrm{C} 1$ contained less $\gamma-\mathrm{Ca}_{2} \mathrm{SiO}_{4}$ than the clinker $\mathrm{C} 0$ at $1200-1300{ }^{\circ} \mathrm{C}$, and this may be partially attributed to the stabilization of $\beta-\mathrm{Ca}_{2} \mathrm{SiO}_{4}$ caused by the foreign ions from the De-S slag. These results are in accord with a previous study [33], which noted that the initial temperatures related to clinker phase reactions decreased significantly when the amount of $\mathrm{CaF}_{2}$ in the raw mixes increased. Yamashita and Tanaka [36] reported that sulfur enhanced the effects of $\mathrm{CaF}_{2}$ on the clinkerization reactions and the amounts of clinker phases. Since the De-S slag contained both fluoride and sulfur, this may intensify the influence on the formation of clinker phases.

\subsection{Description of Clinkerization and Grindability}

Figure 7 shows the thermo-gravimetry (TG) and differential scanning calorimetry (DSC) curves of the cement raw mixes $\mathrm{C} 0$ and $\mathrm{C} 1$. In the TG curves, there were two significant weight losses observed in both the raw mixes. The first weight loss at $400-500{ }^{\circ} \mathrm{C}$ is related to the dehydroxylation of the $\mathrm{Ca}(\mathrm{OH})_{2}$, and the second one between 550 and $700{ }^{\circ} \mathrm{C}$ is associated with the decarbonation of $\mathrm{CaCO}_{3}$. It was found that these two raw mixes have similar dehydroxylation and decarbonation reactions. In terms of DSC curves, the endothermic reactions corresponding to the dehydroxylation of $\mathrm{Ca}(\mathrm{OH})_{2}$ and the decarbonation of $\mathrm{CaCO}_{3}$ were also recorded. Like the results of the TG curves, the decomposition reactions occurring in the raw mix $\mathrm{C} 1$ were similar to those in the raw mix $\mathrm{C} 0$. These results are compatible with some previous studies [33,37], which indicated that the decomposition temperatures of $\mathrm{Ca}(\mathrm{OH})_{2}$ and $\mathrm{CaCO}_{3}$ were not affected in the presence of fluoride and sulfate. However, there was a significant difference in clinkerization between the raw mixes. The raw mix $\mathrm{C} 0$ had a solid, single reaction near $1350^{\circ} \mathrm{C}$, whereas the raw mix $\mathrm{C} 1$ had serial reactions approximately between 1300 and $1340{ }^{\circ} \mathrm{C}$. Telschow et al. [4] indicated that the melt phase normally occurred near $1338^{\circ} \mathrm{C}$, and affected the subsequent reactions that are related to the formation of $\mathrm{Ca}_{3} \mathrm{SiO}_{5}$. It is noted that the clinkerization process was modified by the addition of De-S slag, and the reactions in the temperature range are probably related to the formation of the melt phase and $\mathrm{Ca}_{3} \mathrm{SiO}_{5}$. The reactions in the raw 
mix $\mathrm{C} 1$ began to take place at a relatively low temperature, which would explain why the clinker $\mathrm{C} 1$ contained more $\mathrm{Ca}_{3} \mathrm{SiO}_{5}$ than the clinker $\mathrm{C} 0$ at $1300^{\circ} \mathrm{C}$. Dominguez et al. [33] used differential thermal analysis to examine the sinterization of Portland clinker doped with $\mathrm{CaF}_{2}$, and the results indicated that the peak related to the formation of clinker phases shifted to a lower temperature when adding $0.2-0.4 \mathrm{wt} \%$ of $\mathrm{CaF}_{2}$ to the raw mixes.

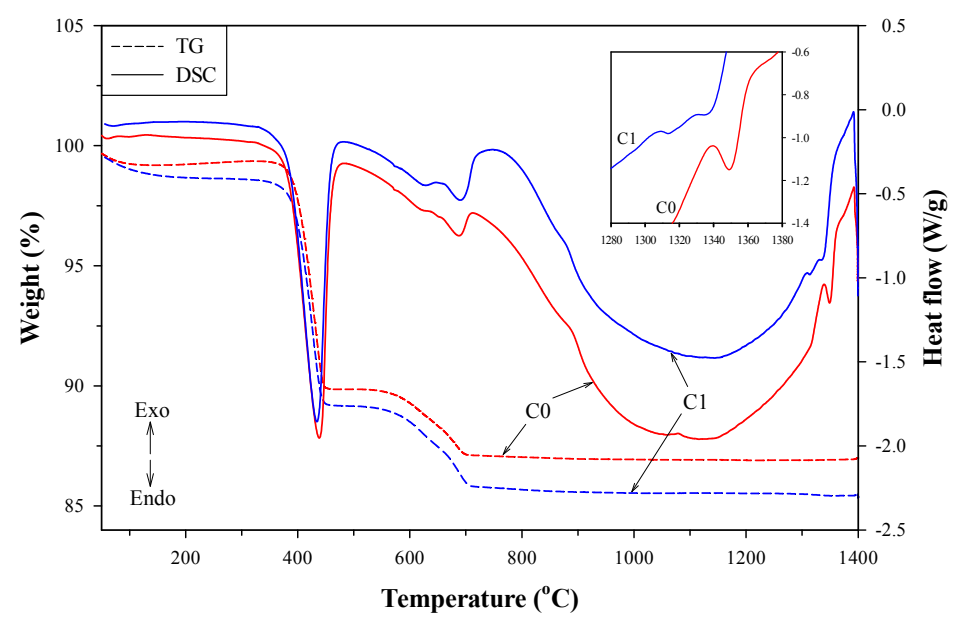

Figure 7. Thermo-gravimetry (TG) and differential scanning calorimetry (DSC) curves of the raw mixes $\mathrm{C} 0$ and $\mathrm{C} 1$ between ambient temperature and $1400^{\circ} \mathrm{C}$.

After the sintering and cooling processes, the clinkers were crushed and ground into powder by means of an identical ball-milling process, and the particle size distribution was determined. Figure 8 shows the particle size distribution of ordinary Portland cement (OPC), and the clinkers C0 and C1 sintered at $1400{ }^{\circ} \mathrm{C}$. The particle size distribution of the clinker $\mathrm{C} 1$ was very similar to that of the commercial OPC product, but different from that of the clinker C0. The clinker C1 had more fine particles than the clinker $\mathrm{C} 0$ under the same milling conditions. Yamashita and Tanaka [36] reported that the clinker produced with $\mathrm{CaF}_{2}$ and $\mathrm{CaSO}_{4}$ had a higher Blaine specific surface area than the normal clinker, a finding that is consistent with the results of this study. This suggests that the use of De-S slag as a raw material in cement production may improve the grindability of the resulting clinkers, which should reduce the amount of electricity needed for clinker grinding.

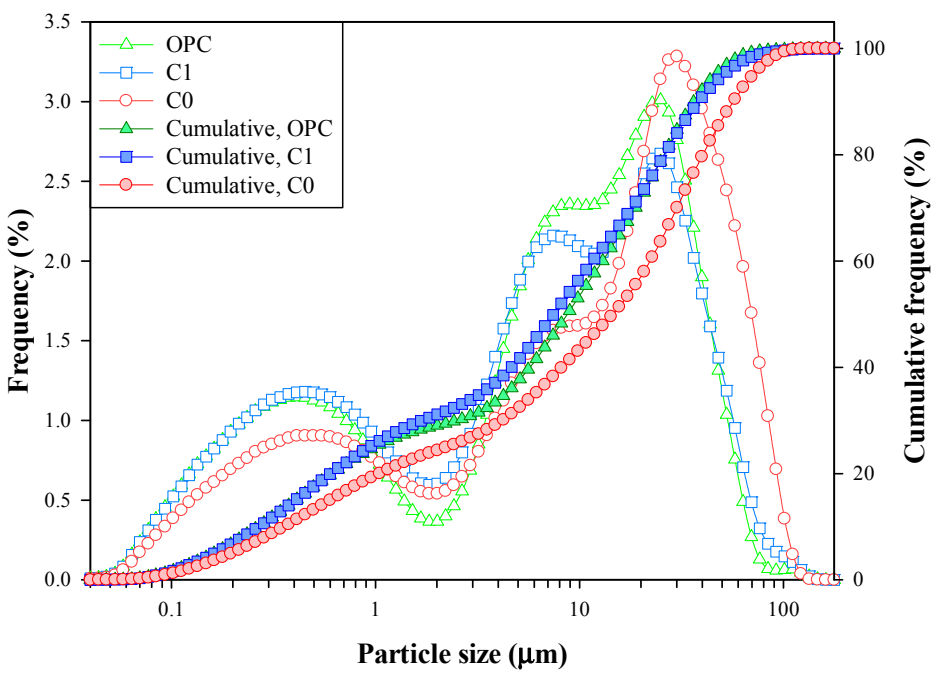

Figure 8. Particle size distribution of ordinary Portland cement (OPC) and the clinkers C0 and C1 sintered at $1400{ }^{\circ} \mathrm{C}$. 


\section{Conclusions}

The following conclusions can be drawn from the present study concerning the use of De-S slag in cement clinker production. In terms of chemical compositions, $\mathrm{Ca}$ and $\mathrm{Si}$ were the major elements in the De-S slag, which shows that the slag has potential for use as a cement raw material. However, some impurities, such as sulfur and fluoride, were also present in small amounts and may affect the formation of clinker phases. The results of the TCLP test showed that the De-S slag was considered non-toxic because no heavy metal were leached out, and thus the external reuse or recycling of the De-S slag should be allowed in Taiwan. When reusing De-S slag as a raw material in clinker production, the quantity of $\mathrm{Ca}_{3} \mathrm{SiO}_{5}$ at $1400{ }^{\circ} \mathrm{C}$ decreased as the amount of De-S slag added increased, and $\mathrm{Ca}_{11}\left(\mathrm{SiO}_{4}\right)_{4} \mathrm{O}_{2} \mathrm{~S}$ was found in the clinkers produced with high amounts of De-S slag. The results of the fusibility test demonstrated that the melting status of clinkers became more significant with an increase in the amount of De-S slag, which means more melt phase formed during clinker sintering. The decrease in the quantity of $\mathrm{Ca}_{3} \mathrm{SiO}_{5}$ is probably due to the excess melt phase. The intermediates, interstitial phases, and even $\mathrm{Ca}_{2} \mathrm{SiO}_{4}$ and $\mathrm{Ca}_{3} \mathrm{SiO}_{5}$ dissolved in the melt phase, and this consequently left a large amount of $\mathrm{CaO}$ persisting in the clinkers. The clinkers produced with $5.4 \mathrm{wt} \%$ of the De-S slag at $1400^{\circ} \mathrm{C}$ had a mineralogical composition similar to that of the reference clinker. The influence of De-S slag was insignificant at $1200-1250{ }^{\circ} \mathrm{C}$, but became considerable above $1250{ }^{\circ} \mathrm{C}$. The temperature range between 1300 and $1350^{\circ} \mathrm{C}$ seems to be a crucial stage in the clinkerization process, at which the amount of $\mathrm{Ca}_{3} \mathrm{SiO}_{5}$ drastically increased, whereas that of $\mathrm{Ca}_{2} \mathrm{SiO}_{4}$ decreased simultaneously. The De-S slag added can lower the initial temperature of the clinkerization reactions, and make the resulting clinker contain more $\mathrm{Ca}_{3} \mathrm{SiO}_{5}$ at $1300{ }^{\circ} \mathrm{C}$. In consideration of the amount used and the effects on clinkerization reactions, the De-S slag may be regarded as a flux in the cement clinker production. An additional benefit brought about by reusing De-S slag in cement clinker production is its potential for reducing the electricity needed for clinker grinding. Moreover, the reduction in burning temperature and electricity use means that the $\mathrm{CO}_{2}$ emissions of the cement industry can be reduced. Reusing desulfurization slag in the cement clinker production also prevents it from being wasted, thus avoiding the problem of waste treatments and potential environmental pollution.

Acknowledgments: The authors gratefully acknowledge the Ministry of Science and Technology, Taiwan, for its financial support of this study (Contract No. MOST 106-3114-E-006-007 and MOST 106-3113-E-007-002).

Author Contributions: Ying-Liang Chen conceived and designed the experiments and wrote the paper; Juu-En Chang contributed experimental materials, reagents, and analysis tools. Ming-Sheng Ko analyzed the data.

Conflicts of Interest: The authors declare no conflict of interest.

\section{References}

1. Van Oss, H.G.; Padovani, A.C. Cement Manufacture and the Environment: Part I: Chemistry and Technology. J. Ind. Ecol. 2002, 6, 89-105.

2. European Cement Association (CEMBUREAU). Activity Report 2016; European Cement Association: Brussels, Belgium, 2016.

3. Mikulčić, H.; Klemeš, J.J.; Vujanović, M.; Urbaniec, K.; Duić, N. Reducing greenhouse gasses emissions by fostering the deployment of alternative raw materials and energy sources in the cleaner cement manufacturing process. J. Clean. Prod. 2016, 136, 119-132. [CrossRef]

4. Telschow, S.; Frandsen, F.; Theisen, K.; Dam-Johansen, K. Cement formation-A success story in a black box: High temperature phase formation of Portland cement clinker. Ind. Eng. Chem. Res. 2012, 51, 10983-11004. [CrossRef]

5. Aruntaş, H.Y.; Gürü, M.; Dayı, M.; Tekin, İ. Utilization of waste marble dust as an additive in cement production. Mater. Des. 2010, 31, 4039-4042. [CrossRef]

6. Chen, H.; Ma, X.; Dai, H. Reuse of water purification sludge as raw material in cement production. Cem. Concr. Compos. 2010, 32, 436-439. [CrossRef] 
7. Husillos Rodríguez, N.; Martínez-Ramírez, S.; Blanco-Varela, M.T.; Donatello, S.; Guillem, M.; Puig, J.; Fos, C.; Larrotcha, E.; Flores, J. The effect of using thermally dried sewage sludge as an alternative fuel on Portland cement clinker production. J. Clean. Prod. 2013, 52, 94-102. [CrossRef]

8. Tsakiridis, P.E.; Agatzini-Leonardou, S.; Oustadakis, P. Red mud addition in the raw meal for the production of Portland cement clinker. J. Hazard. Mater. 2004, 116, 103-110. [CrossRef] [PubMed]

9. Wu, K.; Shi, H.; Guo, X. Utilization of municipal solid waste incineration fly ash for sulfoaluminate cement clinker production. Waste Manag. 2011, 31, 2001-2008. [CrossRef] [PubMed]

10. Schneider, M.; Romer, M.; Tschudin, M.; Bolio, H. Sustainable cement production-Present and future. Cem. Concr. Res. 2011, 41, 642-650. [CrossRef]

11. Xu, W.; Xu, J.; Liu, J.; Li, H.; Cao, B.; Huang, X.; Li, G. The utilization of lime-dried sludge as resource for producing cement. J. Clean. Prod. 2014, 83, 286-293. [CrossRef]

12. Monshi, A.; Asgarani, M.K. Producing Portland cement from iron and steel slags and limestone. Cem. Concr. Res. 1999, 29, 1373-1377. [CrossRef]

13. Bernardo, G.; Marroccoli, M.; Nobili, M.; Telesca, A.; Valenti, G.L. The use of oil well-derived drilling waste and electric arc furnace slag as alternative raw materials in clinker production. Resour. Conserv. Recycl. 2007, 52, 95-102. [CrossRef]

14. Tsakiridis, P.E.; Papadimitriou, G.D.; Tsivilis, S.; Koroneos, C. Utilization of steel slag for Portland cement clinker production. J. Hazard. Mater. 2008, 152, 805-811. [CrossRef] [PubMed]

15. Huang, L.-J.; Wang, H.-Y.; Wei, C.-T. Engineering properties of controlled low strength desulfurization slags (CLSDS). Constr. Build. Mater. 2016, 115, 6-12. [CrossRef]

16. Wu, Q.; You, R.; Clark, M.; Yu, Y. Pb(II) removal from aqueous solution by a low-cost adsorbent dry desulfurization slag. Appl. Surf. Sci. 2014, 314, 129-137. [CrossRef]

17. Sheng, G.; Huang, P.; Wang, S.; Chen, G. Potential reuse of slag from the Kambara reactor desulfurization process of iron in an acidic mine drainage treatment. J. Environ. Eng. 2014, 140, 04014023. [CrossRef]

18. Kolovos, K.; Loutsi, P.; Tsivilis, S.; Kakali, G. The effect of foreign ions on the reactivity of the $\mathrm{CaO}-\mathrm{SiO}_{2}-\mathrm{Al}_{2} \mathrm{O}_{3}-\mathrm{Fe}_{2} \mathrm{O}_{3}$ system: Part I. Anions. Cem. Concr. Res. 2001, 31, 425-429. [CrossRef]

19. Kolovos, K.; Tsivilis, S.; Kakali, G. The effect of foreign ions on the reactivity of the $\mathrm{CaO}-\mathrm{SiO}_{2}-\mathrm{Al}_{2} \mathrm{O}_{3}-\mathrm{Fe}_{2} \mathrm{O}_{3}$ system: Part II: Cations. Cem. Concr. Res. 2002, 32, 463-469. [CrossRef]

20. Kolovos, K.; Tsivilis, S.; Kakali, G. Study of clinker dopped with P and S compounds. J. Therm. Anal. Calorim. 2004, 77, 759-766. [CrossRef]

21. Kacimi, L.; Simon-Masseron, A.; Ghomari, A.; Derriche, Z. Influence of NaF, $\mathrm{KF}$ and $\mathrm{CaF}_{2}$ addition on the clinker burning temperature and its properties. C. R. Chim. 2006, 9, 154-163. [CrossRef]

22. Camargo, J.A. Fluoride toxicity to aquatic organisms: A review. Chemosphere 2003, 50, 251-264. [CrossRef]

23. US Environmental Protection Agency (USEPA). Methods for Chemical Analysis of Water and Wastes, Method 340.2: Fluoride; US Environmental Protection Agency (USEPA): Cincinnati, OH, USA, 1991.

24. USEPA. SW-846 Method 1311: Toxicity Characteristic Leaching Procedure; US Environmental Protection Agency (USEPA): Washington, DC, USA, 1992.

25. Hillier, S. Use of an air brush to spray dry samples for X-ray powder diffraction. Clay Miner. 1999, 34, 127-135. [CrossRef]

26. Cullity, B.D.; Stock, S.R. Elements of X-ray Diffraction; Prentice Hall: Upper Saddle River, NJ, USA, 2001.

27. Jenkins, R.; Snyder, R.L. Introduction to X-ray Powder Diffractometry; John Wiley \& Sons: New York, NY, USA, 1996.

28. Snyder, R.L. The use of reference intensity ratios in X-ray quantitative analysis. Powder Diffr. 1992, 7, $186-193$. [CrossRef]

29. American Society for Testing and Materials (ASTM). D1857/D1857M-17 Standard Test Method for Fusibility of Coal and Coke Ash; ASTM International: West Conshohocken, PA, USA, 2017.

30. Jeon, I.-Y.; Shin, S.-H.; Jung, S.-M.; Choi, H.-J.; Xu, J.; Baek, J.-B. One-pot purification and iodination of waste Kish graphite into high-quality electrocatalyst. Part. Part. Syst. Charact. 2017. [CrossRef]

31. McKeown, D.A.; Muller, I.S.; Gan, H.; Pegg, I.L.; Stolte, W.C. Determination of sulfur environments in borosilicate waste glasses using X-ray absorption near-edge spectroscopy. J. Non-Cryst. Solids 2004, 333, 74-84. [CrossRef]

32. Taylor, H.F.W. Cement Chemistry, 2nd ed.; Thomas Telford: London, UK, 1997. 
33. Dominguez, O.; Torres-Castillo, A.; Flores-Velez, L.M.; Torres, R. Characterization using thermomechanical and differential thermal analysis of the sinterization of Portland clinker doped with $\mathrm{CaF}_{2}$. Mater. Charact. 2010, 61, 459-466. [CrossRef]

34. Bădănoiu, A.; Paceagiu, J.; Voicu, G. Hydration and hardening processes of Portland cements obtained from clinkers mineralized with fluoride and oxides. J. Therm. Anal. Calorim. 2011, 103, 879-888. [CrossRef]

35. Chan, C.J.; Kriven, W.M.; Young, J.F. Physical stabilization of the $\beta \rightarrow \gamma$ transformation in dicalcium silicate. J. Am. Ceram. Soc. 1992, 75, 1621-1627. [CrossRef]

36. Yamashita, M.; Tanaka, H. Low-temperature burnt Portland cement clinker using mineralizer. Cem. Sci. Concr. Technol. 2011, 65, 82-87. [CrossRef]

37. Zhou, Y.; Robl, T.; Henke, K. Synthesis of pure tricalcium silicate with calcium sulfate and calcium fluoride as mineralizers. J. Chin. Ceram. Soc. 2014, 42, 601-606.

(C) 2017 by the authors. Licensee MDPI, Basel, Switzerland. This article is an open access article distributed under the terms and conditions of the Creative Commons Attribution (CC BY) license (http:/ / creativecommons.org/licenses/by/4.0/). 